\title{
SYNTHESIS, CRYSTAL STRUCTURE ANALYSIS AND CHARACTERIZATION OF MERCURY(II) COMPLEX CONTAINING 2-(AMINOMETHYL)PYRIDINE AND BROMIDE
}

\author{
SADIF A. SHIRVAN, * FEREYDOON KHAZALI, SARA HAYDARI DEZFULI, AND ALI BORSALANI
}

Department of Chemistry, Omidieh Branch, Islamic Azad University, Omidieh, Iran

\begin{abstract}
The new complex of $\left[\mathrm{Hg}(2-\mathrm{AMPy})_{2} \mathrm{Br}_{2}\right]_{2} \cdot \mathrm{HgBr}_{4}$ (1) was synthesized from the reaction of $\mathrm{HgBr}_{2}$ with 2-(aminomethyl)pyridine (2-AMPy) in methanolic solution. Suitable crystals of $\mathbf{1}$ for diffraction experiment was obtained by slow evaporation from DMSO. Resulted complex was characterized by IR, elemental analysis, thermal analysis and single crystal X-ray diffraction. In this compound, two five-coordinated mercury centers in the cationic parts have slightly and highly distorted square-based pyramidal geometries by the trigonal-indexes, $\tau_{5}$, of 0.18 and 0.49 , respectively. According to four-coordinate geometry index, $\tau 4$, of 0.95 , anionic part has perfect tetrahedral geometry.
\end{abstract}

Keywords: $\operatorname{Hg}(\mathrm{II}), 2$-(aminomethyl)pyridine ligand, crystal structure, thermal gravimetric analyses.

\section{INTRODUCTION}

2-(Aminomethyl)pyridine ligand, 2-AMPy, as an N,N'-bidentate ligand containing both aromatic pyridine aliphatic amine donor function, Scheme 1, is well-known. There are many reports on the coordination chemistry of different metals including this ligand. But it is to be noted, there is only one report on the complexation of mercury to this ligand. ${ }^{1}$

On the other hand, crystal structure of five mercury complexes with the formula of of $\left[\mathrm{Hg}(\mathrm{N}-\mathrm{N})_{2} \mathrm{X}\right]$ have been reported including 2,2'-bipyridine, 1,10-phenanthroline, 3-(2-fluorophenyl)-1-(4-nitrophenyl)triazenide molecules as N-N bidentate ligands and pyridien, thiocyanate, saccharinato and triflate as mono-dentate ligand. ${ }^{1-4}\left[\mathrm{Hg}(\text { bipy })_{2}\left(\mathrm{CF}_{3} \mathrm{COO}\right)\right]$ has been reported in Halfpenny and Small in 1997 by two different counter cations. ${ }^{2}$ In 2004 , Mahjoub and co-workers has been reported structure of $\left[\mathrm{Hg}(\mathrm{bipy})_{2}(\mathrm{SCN})\right]^{3}$ Crystal structures of $\left[\mathrm{Hg}(\text { phen })_{2}(\mathrm{sach})\right]$ and $\left[\mathrm{Hg}(\text { triAz) })_{2}(\right.$ py $\left.)\right]$ have been studied by Batsanov et al. and Horner et.al. in $2011^{4}$ and $2006^{5}$, respectively. In these formula, "bipy" is 2,2'-bipyridine, "phen" is 1,10-phenanthroline, "py" is pyridien, "sach" is saccharinato and "triAz" is 3-(2-fluorophenyl)-1(4-nitrophenyl)triazenide). So there is no structural reports with the formula of $\left[\mathrm{Hg}(2-\mathrm{AMPy})_{2} \mathrm{X}\right]$ (where "2-AMPy" is 2-(aminomethyl)pyridine) in the literature. On the other hand there is only one report on the complexation of mercury to this ligand by the formula of $\left[\mathrm{Hg}(2-\mathrm{AMPy})_{2}(\mathrm{sach})_{2}\right] .{ }^{1}$ In Yilmaz and co-workers paper in 2004, a bis(saccharinato) complex of mercury(II) with 2-(aminomethyl)pyridine was synthesized and characterized by single crystal $\mathrm{X}$-ray diffraction. Herein, we report the synthesis, characterization and crystal structure of a new mercury(II) complex containing 2-(aminomethyl)pyridine as an example of five-coordinated $\mathrm{Hg}$ complexes containing this ligand.

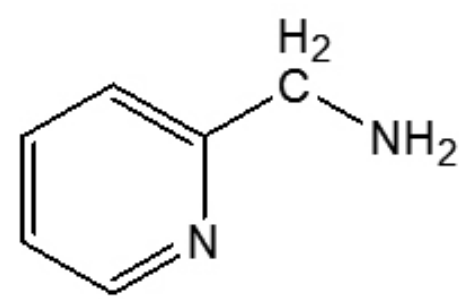

Scheme 1. 2-(aminomethyl)pyridine ligand, 2-AMPy.

\section{EXPERIMENTAL}

\section{Materials and Physical Methods}

$\mathrm{HgBr}_{2}$ and 2-(Aminomethyl)pyridine were purchased from Aldrich and used as received. Other materials were purchased from Merck and used without further purification. Infrared spectra $\left(4000-250 \mathrm{~cm}^{-1}\right)$ of solid samples were taken as $1 \%$ dispersion in CsI pellets using a Shimadzu-470 spectrometer. Elemental analysis was performed using a Heraeus CHN-O Rapid analyzer.
Melting point was obtained by a Kofler Heizbank Rechart type 7841 melting point apparatus.

\section{Synthesis of $\left[\mathrm{Hg}(2-\mathrm{AMPy})_{2} \mathrm{Br}\right]_{2} \cdot \mathrm{HgBr}_{4}(\mathbf{1})$}

2-(Aminomethyl)pyridine $(0.4 \mathrm{ml}, 4 \mathrm{mmol})$ and $\mathrm{HgBr}_{2}(1.08 \mathrm{~g}, 3 \mathrm{mmol})$ were dissolved separately in methanol $(25 \mathrm{ml})$ and then mixed. Resulted solution was stirred $48 \mathrm{~h}$ at room temperature. A white precipitate formed that was filtered off. Suitable crystals for X-ray diffraction measurement were obtained by slow evaporation from DMSO over two weeks (yield 1.00 g, $68.0 \%$, m.p. $270{ }^{\circ} \mathrm{C}$-decomposed). IR (CsI, cm $\left.{ }^{-1}\right): 3320 \mathrm{w}, 3260 \mathrm{w}, 1579 \mathrm{w}$, $1481 \mathrm{w}, 1428 \mathrm{~m}, 1286 \mathrm{~m}, 1152 \mathrm{~s}, 995 \mathrm{~s}, 922 \mathrm{~s}, 767 \mathrm{~s}, 713 \mathrm{~m}, 632 \mathrm{~m}, 457 \mathrm{~s}$ and $406 \mathrm{~s}$. Anal. Calcd. C, 19.04; H, 2.13; N, 7.41. Found: C, 19.09; H, 2.20; N, 7.45\%.

Crystallographic Data Collection and Structure Determination

The X-ray diffraction measurement was made on a Bruker APEX II CCD (Karlsruhe, Germany) area detector diffractometer at $298 \mathrm{~K}$ and with Mo-K $\alpha$ radiation, graphite monochromator, $\lambda=0.71073 \AA$. The structure of 1 was solved by SHELX-97 and absorption correction was done using the SADABS programs. ${ }^{6}$ Data collection, cell refinement, and data reduction was done by APEX II, SAINT, SHELXTL, PLATON, and MERCURY software. ${ }^{6-9}$

\section{RESULTS AND DISCUSSION}

Synthesis and characterization of $\left[\mathrm{Hg}(2-\mathrm{AMPy})_{2} \mathrm{Cl}\right] . \mathrm{HgCl}_{4}(1)$

Complex 1 was synthesized by the reaction of 2 -(aminomethyl)pyridine (2-AMePy) and $\mathrm{HgBr}_{2}$ and in 4:3 molar ratio in methanol at room temperature during $48 \mathrm{~h}$, as shown in below scheme:

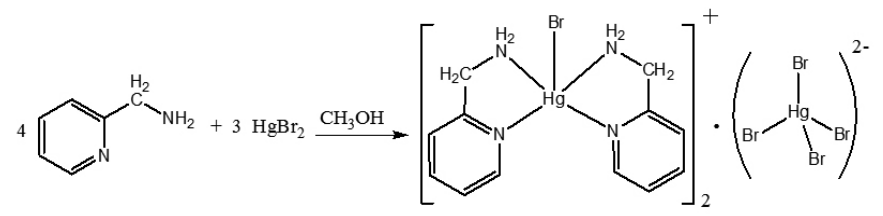

Suitable crystals for X-ray diffraction analysis of $\mathbf{1}$, was obtained for X-ray diffraction measurement by slow evaporation from DMSO solution after two weeks.

Spectroscopic characterization of $\left[\mathrm{Hg}(2-\mathrm{AMPy})_{2} \mathrm{Br}\right], \mathrm{HgBr}_{4}$ (1)

IR absorptions of $\mathbf{1}$ have been listed in the experimental part. The infrared spectrum for this complex shows several bands in the region of 3320-3260 $\mathrm{cm}^{-}$ 1 , which are assigned to the $\mathrm{C}-\mathrm{H}$ stretching vibrations of the pyridine ring and $\mathrm{CH}_{2}$ group. The stretching of $\mathrm{C}=\mathrm{C}$ and $\mathrm{C}=\mathrm{N}$ in the pyridine moiety appears at 1579 and $1481 \mathrm{~cm}^{-1}$. It is notable that strong bands at the region of 1286-632 $\mathrm{cm}^{-1}$ correspond to the $\mathrm{H}_{2} \mathrm{C}-\mathrm{NH}_{2}$ stretching, $\mathrm{H}-\mathrm{N}-\mathrm{H}$ wagging and deformation of $\mathrm{C}=\mathrm{C}=\mathrm{N}$ and $\mathrm{C}=\mathrm{C}=\mathrm{C}$ in the pyridine rings ${ }^{10-13} \mathrm{Far}$ infrared spectrum of complex 1 was recorded between 500 and $300 \mathrm{~cm}^{-1}$. Vibrations that apear at 457 and 406 $\mathrm{cm}^{-1}$ can be corresponde to $\mathrm{Hg}-\mathrm{Br}$ and $\mathrm{Hg}-\mathrm{N}$ stretchings vibrations. ${ }^{14}$ 
Thermal studies of $\left[\mathrm{Hg}(2-\mathrm{AMPy})_{2} \mathrm{Br}_{2} \cdot \mathrm{HgBr}_{4}(1)\right.$

The thermal stability of $\mathbf{1}$ has been determined on single-crystalline samples between $30-550{ }^{\circ} \mathrm{C}$ in an air atmosphere with a heating rate of 10 ${ }^{\circ} \mathrm{C} \mathrm{min}^{-1}$ by thermogravimetric analysis (TGA), Figure 1. The TGA curve shows that compound $\mathbf{1}$ decomposed in two steps. In the first one, chemical decomposition starts at about $95^{\circ} \mathrm{C}$ and ends around $120^{\circ} \mathrm{C}$ with the weight loss of $\sim 30 \%$ corresponds to the removing of 2-(aminomethyl)pyridine ligand (calcd. 28.6\%). Second one starts at about $210^{\circ} \mathrm{C}$ and ends around $280{ }^{\circ} \mathrm{C}$ with the weight loss of $\sim 31 \%$ corresponds to the removing of iodine ligands (calcd. $31.7 \%$ ). The remaining weight of $\sim 40 \%$ is corresponded to the $\mathrm{HgO}$ (calcd. $39.8 \%)$.

Table 1. Crystallographic and structure refinement data for $[\mathbf{H g}(2-$ AMPy) $\left.)_{2}\right]_{2} \cdot \mathrm{HgBr}_{4}(1)$.

\begin{tabular}{|c|c|}
\hline Formula & $\mathrm{C}_{24} \mathrm{H}_{32} \mathrm{Br}_{6} \mathrm{Hg}_{3} \mathrm{~N}_{8}$ \\
\hline Formula weight & 1513.75 \\
\hline Temperature /K & $298(2)$ \\
\hline Wavelength $\lambda / \AA$ & 0.71073 \\
\hline Crystal system & Triclinic \\
\hline Space Group & $P \overline{1}$ \\
\hline$a / \AA$ & $7.5548(7)$ \\
\hline$b / \AA$ & $13.8951(13)$ \\
\hline$c / \AA$ & $18.9649(19)$ \\
\hline$\alpha /^{\circ}$ & 109.947(7) \\
\hline$\beta /{ }^{\circ}$ & $91.849(8)$ \\
\hline$\gamma /{ }^{\circ}$ & $101.562(7)$ \\
\hline Volume $/ \AA^{3}$ & $1822.4(3$ \\
\hline$Z$ & 2 \\
\hline Density (calc.) $/ \mathrm{g} \mathrm{cm}^{-1}$ & 2.759 \\
\hline$\theta$ ranges for data collection & $1.60-29.27$ \\
\hline $\mathrm{F}(000)$ & 1364 \\
\hline Absorption coefficient $\mathrm{mm}^{-1}$ & 19.210 \\
\hline \multirow[t]{3}{*}{ Index ranges } & $-10 \leq \mathrm{h} \leq 10$ \\
\hline & $18 \leq \mathrm{k} \leq 19$ \\
\hline & $26 \leq 1 \leq 25$ \\
\hline Data collected & 20627 \\
\hline Unique data $\left(R_{\text {int }}\right)$ & $9763,0.1003$ \\
\hline Completeness to theta & 98.5 \\
\hline Parameters, restrains & 371,0 \\
\hline Final $R_{1}, w R_{2}$ (Obs. data) & $0.0317,0.1211$ \\
\hline Final $R_{1}, w R_{2}$ (All data) & $0.0410,0.1310$ \\
\hline Goodness of fit on $F^{2}(\mathrm{~S})$ & 1.090 \\
\hline Largest diff peak and hole/e. $\AA^{-3}$ & $1.010,-1.009$ \\
\hline $\mathrm{CCDC}$ & 1470539 \\
\hline
\end{tabular}

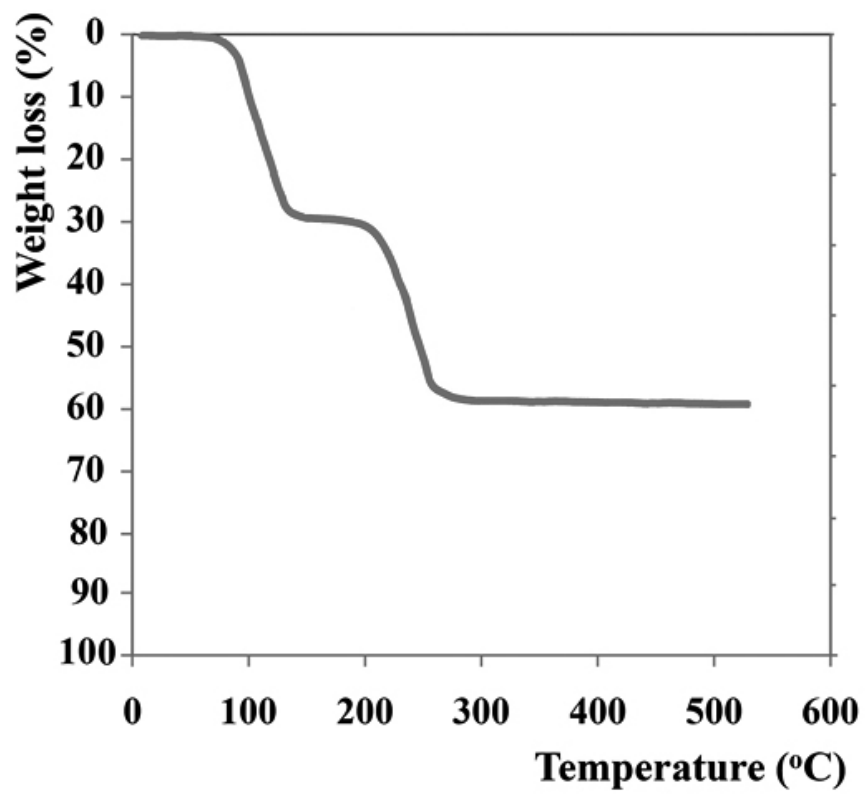

Figure 1. Thermogravimetric analysis of $\left[\mathrm{Hg}(2-\mathrm{AMPy})_{2} \mathrm{Br}_{2} \cdot \mathrm{HgBr}_{4}(\mathbf{1})\right.$.

Table 2. Bond distances $(\AA)$ and bond angles $\left({ }^{\circ}\right)$ for $\left[\mathbf{H g}(2-\mathbf{A M P y})_{2} \mathbf{B r}\right]_{2}$. $\mathrm{HgBr}_{4}$ (1).

\begin{tabular}{|c|c|c|c|}
\hline Hg1-N1 & $2.23(2)$ & N1-Hg1-Br1 & $131.0(9)$ \\
\hline Hg1-N2 & $2.55(2)$ & N2-Hg1-Br1 & $94.0(4)$ \\
\hline Hg1-N3 & $2.362(19)$ & N3-Hg1-Br1 & $128.7(5)$ \\
\hline Hg1-N4 & $2.452(19)$ & N4-Hg1-Br1 & $93.2(4)$ \\
\hline Hg2-N5 & $2.33(2)$ & N5-Hg2-N6 & $72.8(8)$ \\
\hline Hg2-N6 & $2.37(2)$ & N5-Hg2-N7 & $107.9(12)$ \\
\hline Hg2-N7 & $2.40(3)$ & N5-Hg2-N8 & $89.0(9)$ \\
\hline Hg2-N8 & $2.46(2)$ & N6-Hg2-N7 & $105.9(9)$ \\
\hline Hg1-Br1 & $2.548(2)$ & N6-Hg2-N8 & $159.3(7)$ \\
\hline Hg2-Br2 & $2.568(3)$ & N7-Hg2-N8 & $69.7(7)$ \\
\hline Hg3-Br3 & $2.574(2)$ & N5-Hg2-Br2 & $148.4(8)$ \\
\hline Hg3-Br4 & $2.649(3)$ & N6-Hg2-Br2 & $98.2(5)$ \\
\hline Hg3-Br5 & $2.614(3)$ & N7-Hg2-Br2 & $103.8(9)$ \\
\hline Hg3-Br6 & $2.580(3)$ & N8-Hg2-Br2 & $102.5(5)$ \\
\hline N1-Hg1-N2 & $69.3(8)$ & Br3-Hg3-Br4 & $106.68(9)$ \\
\hline N1-Hg1-N3 & $97.9(11)$ & Br3-Hg3-Br5 & $112.20(9)$ \\
\hline N1-Hg1-N4 & $118.0(8)$ & Br3-Hg3-Br6 & $113.57(9)$ \\
\hline N2-Hg1-N3 & $89.2(7)$ & Br4-Hg3-Br5 & $103.57(9)$ \\
\hline N2-Hg1-N4 & $160.5(7)$ & Br4-Hg3-Br6 & $110.95(11)$ \\
\hline N3-Hg1-N4 & $72.2(6)$ & Br5-Hg3-Br6 & $109.38(11)$ \\
\hline
\end{tabular}

Single crystal X-ray diffraction study of $\left[\mathrm{Hg}(2-\mathrm{AMPy})_{2} \mathrm{Br}_{2} \cdot \mathrm{HgBr}_{4}(1)\right.$

The asymmetric unit and the atom numbering scheme for complex 1 is shown in Figure 2. Selected bond distances and bond angles of interest are listed in Table 2 . This compound crystallizes in the triclinic $P^{\overline{1}}$ space group. The crystal is comprised of discrete units composed of two [ $\left.\mathrm{Hg}(2-\mathrm{AMPy})_{2} \mathrm{Br}\right]^{+}$ cations and one $\left[\mathrm{HgBr}_{4}\right]^{2-}$ dianion. In the anionic part of this compound, $[\mathrm{HgBr}]^{2-}$, coordination environment around $\mathrm{Hg} 3$ atom is almost perfect tetrahedral with four-coordinated index, $\tau 4$, of $0.95 .{ }^{15}$ The cation part of compound 1 consists of two different $\mathrm{Hg}$ (II) complexes, part A, including $\mathrm{Hg} 1$ atom and part B containing $\mathrm{Hg} 2$ atom. So, in 1, each asymmetric unit 
consists of three crystallographically independent $\mathrm{Hg}$ (II) centers, six bromide ions, and four neutral 2-AMPy ligands. In part $\mathrm{A}, \mathrm{Hg} 1$ is in a highly distorted square-based pyramidal geometry, SBP, with trigonality index, $\tau_{5},{ }^{16}$ of 0.49 , coordinated by two 2-AMPy ligands and one $\mathrm{Br}$ atom in which three nitrogen atoms of two bidentate 2-AMPy ligands $(\mathrm{N} 1, \mathrm{~N} 2, \mathrm{~N} 4)$ and the $\mathrm{Br}$ atom, $\mathrm{Br} 1$, occupy equatorial positions, whereas the fourth $\mathrm{N}$ atom of $\mathrm{NH}_{2}$ groupon ligand, N7, occupies the axial position. The $\mathrm{Hg} 1$ atom is displaced 0.190(3) $\AA$ above the mean basal plane in the direction of an axial N2. On the other hand, in part $\mathrm{B}, \mathrm{Hg} 2$ is in a slightly distorted square-based pyramidal geometry, SBP, with trigonality index, $\tau_{5}$, of 0.18 , coordinated by two 2-AMPy ligands and one $\mathrm{Br}$ atom in which three nitrogen atoms of two bidentate 2-AMPy ligands (N5, N6, $\mathrm{N} 8$ ) and the $\mathrm{Br}$ atom, $\mathrm{Br}$ 2, occupy equatorial positions, whereas the fourth $\mathrm{N}$ atom of $\mathrm{NH}_{2}$ groupon ligand, $\mathrm{N} 7$, occupies the axial position. The $\mathrm{Hg} 2$ atom is displaced $0.271(3) \AA$ above the mean basal plane in the direction of an axial N7. In this compound, the $\mathrm{Hg}-\mathrm{N}$ bond distances are ranged from 2.23(2) $\AA$ to $2.46(2) \AA$, Table 2, that is similar to those reported by Yilmaz and co-workers for bis(saccharinato) complex of mercury(II) with 2-(aminomethyl)pyridine. [1] It is notable that the bond distance difference between $\mathrm{Hg}-\mathrm{N}_{\text {py }}$ and $\mathrm{Hg}-$ $\mathrm{N}_{\text {amine }}$ is less than $0.32 \AA$, while the same difference in Yilmaz and co-workers repport for bis(saccharinato) complex of mercury(II) with 2-(aminomethyl) pyridine is about $0.5 \AA$. Here, also the $\mathrm{Hg}-\mathrm{N}_{\text {amine }}$ distance, $(\mathrm{Hg} 1-\mathrm{N} 1=2.23(2)$, Hg1-N3 = 2.362(19), Hg2-N5 = 2.33(2)and Hg2-N7 = 2.40(3) §), is slightly shorter than the Hg- $\mathrm{N}_{\mathrm{py}}$ distance, $(\mathrm{Hg} 1-\mathrm{N} 2=2.55(2), \mathrm{Hg} 1-\mathrm{N} 4=2.452(19)$, $\mathrm{Hg} 2-\mathrm{N} 6=2.37(2)$ and $\mathrm{Hg} 2-\mathrm{N} 8=2.46(2) \AA)$. The Hg-N and $\mathrm{Hg}-\mathrm{Cl}$ bond distances are in normal ranges. ${ }^{1-5}$

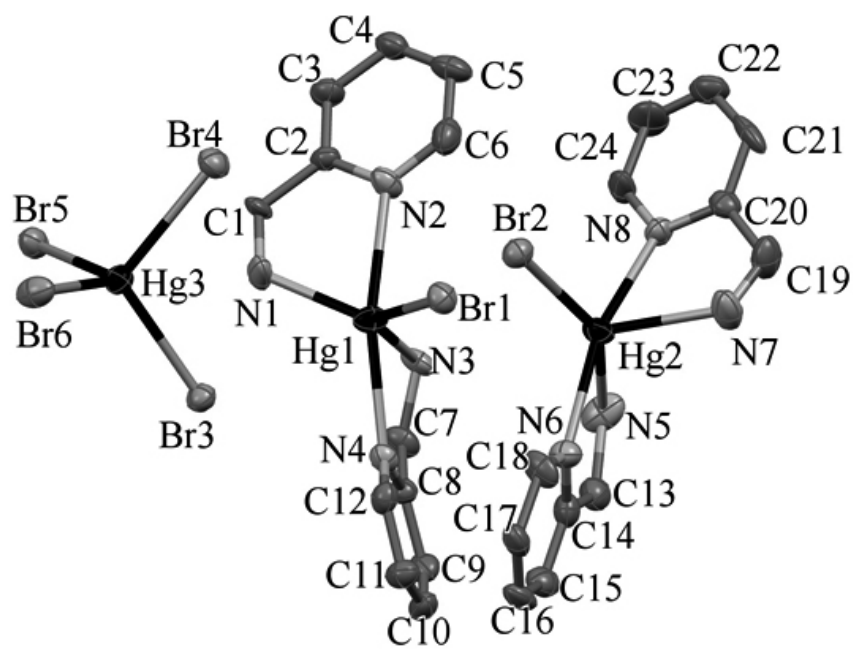

Figure 2. The labeled diagram of $\left[\mathbf{H g}(\mathbf{2}-\mathbf{A M P y})_{2} \mathbf{B r}_{2} \cdot \mathbf{H g B r}_{4}\right.$ (1). Thermal ellipsoids are at $30 \%$ probability level. Hydrogens are omitted for clarity

Table 3. Hydrogen-bond and $\pi_{\mathrm{C} 14-18 N 6} \ldots \pi_{\mathrm{C} 14-18 N 6}$ geometry for $[\mathrm{Hg}(2-$ AMPy) ${ }_{2} \mathbf{B r}_{2} \cdot \mathrm{HgBr}_{4}(\mathbf{1})$ in the crystal packing $\left(\AA,{ }^{\circ}\right)$.

\begin{tabular}{|c|c|c|c|c|c|}
\hline $\mathrm{D}-\mathrm{H} \ldots \mathrm{A}$ & $\begin{array}{c}\mathrm{d} \\
(\mathrm{D} \ldots \mathrm{H})\end{array}$ & $\begin{array}{c}\mathrm{d} \\
(\mathrm{H} \ldots \mathrm{A})\end{array}$ & $\begin{array}{c}\mathrm{d} \\
(\mathrm{D} \ldots \mathrm{A})\end{array}$ & $<$ (DHA) & $\begin{array}{c}\text { Symmetry } \\
\text { Code }\end{array}$ \\
\hline $\mathrm{N} 3-\mathrm{H} 3 \mathrm{~B} \ldots \mathrm{Br} 2$ & 0.90 & 2.830 & 3.67 & 156 & - \\
\hline $\mathrm{N} 5-\mathrm{H} 5 \mathrm{~A} \ldots \mathrm{Br} 1$ & 0.90 & 2.830 & 3.49 & 131 & $1+\mathrm{x}, \mathrm{y}, \mathrm{z}$ \\
\hline $\mathrm{N} 1-\mathrm{H} 1 \mathrm{C} \ldots \mathrm{Br} 6$ & 0.90 & 2.860 & 3.74 & 166 & - \\
\hline $\mathrm{N} 1-\mathrm{H} 1 \mathrm{D} \ldots \mathrm{Br} 3$ & 0.90 & 2.910 & 3.41 & 117 & $-1+\mathrm{x}, \mathrm{y}, \mathrm{z}$ \\
\hline $\mathrm{N} 3-\mathrm{H} 3 \mathrm{~A} \ldots \mathrm{Br} 4$ & 0.90 & 2.730 & 3.63 & 171 & - \\
\hline $\mathrm{N} 5-\mathrm{H} 5 \mathrm{~B} \ldots \mathrm{Br} 5$ & 0.90 & 2.730 & 3.55 & 153 & $\mathrm{x},-1+\mathrm{y}, \mathrm{z}$ \\
\hline $\mathrm{N} 7-\mathrm{H} 7 \mathrm{~A} \ldots \mathrm{Br} 5$ & 0.90 & 2.790 & 3.57 & 146 & $\begin{array}{c}-1+\mathrm{x},- \\
1+\mathrm{y}, \mathrm{z}\end{array}$ \\
\hline $\mathrm{N} 7-\mathrm{H} 7 \mathrm{~B} \ldots \mathrm{Br} 6$ & 0.90 & 2.630 & 3.49 & 161 & $\mathrm{x},-1+\mathrm{y}, \mathrm{z}$ \\
\hline $\mathrm{C} 1-\mathrm{H} 1 \mathrm{~B} \ldots \mathrm{Br} 4$ & 0.97 & 2.810 & 3.62 & 141 & - \\
\hline $\begin{array}{c}\mathrm{N} 23-\mathrm{H} 23 \ldots \\
\mathrm{Cl} 5\end{array}$ & 0.93 & 2.910 & 3.72 & 167 & $1+\mathrm{x}, \mathrm{y}, \mathrm{z}$ \\
\hline $\begin{array}{c}\pi_{\mathrm{C} 14-18 \mathrm{~N} 6} \ldots \pi_{\mathrm{C} 14-} \\
18 \mathrm{~N} 6\end{array}$ & - & - & 4.068 & - & $-\mathrm{x},-\mathrm{y},-\mathrm{z}$ \\
\hline
\end{tabular}
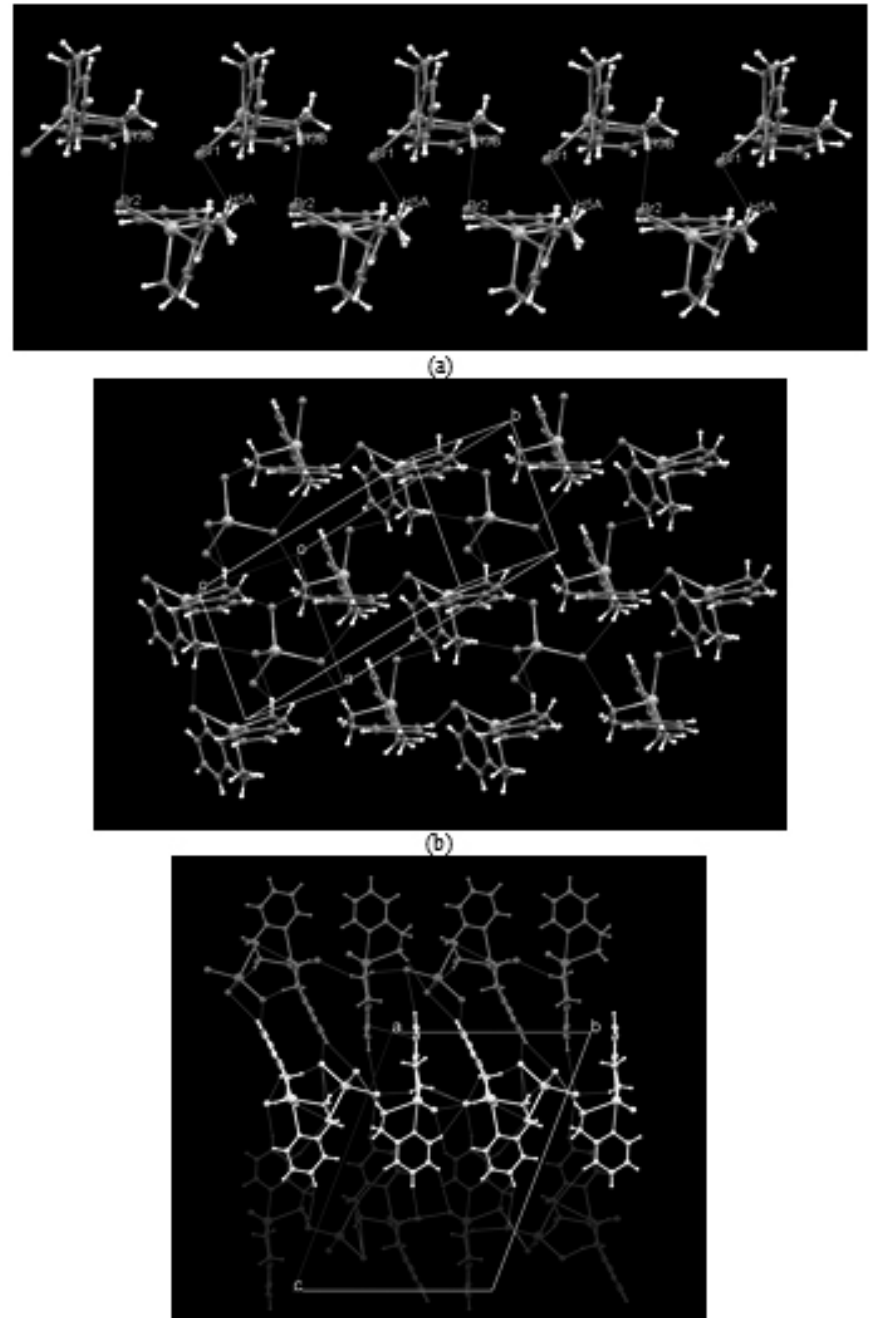

(c)

Figure 3. Crystal packing diagram for $\left[\mathbf{H g}(2-\mathrm{AMPy})_{2} \mathbf{B r}_{2} \cdot \mathrm{HgBr}_{4}(\mathbf{1})\right.$. (a) formation of $1-\mathrm{D}$ linear chains through $\mathrm{N}-\mathrm{H}$...Br hydrogen bonds in a-direction, (b) formation of 2-D sheets by $\mathrm{N}-\mathrm{H}$... Br hydrogen bonds between $\left[\mathrm{Hg}(2-\mathrm{AMPy})_{2} \mathrm{Br}\right]$ of each linear chains and $\mathrm{HgBr}_{4}$ moeities and (c) generation of 3-D structures by cooperation between $\mathrm{C}-\mathrm{H} \ldots \mathrm{Br}, \mathrm{N}-\mathrm{H} \ldots \mathrm{Br}$ and $\pi \ldots \pi$ intermolecular interactions. Intermolecular interactions are shown as dashed lines. Different colors show different adjacent chains or sheets.

In the crystal packing of this compound, adjacent cationic mercury parts are linked by $\mathrm{N}-\mathrm{H} . . . \mathrm{Br}$ hydrogen bonds to form a 1D linear chain spaning along the a-axis, Figure 3(a), Table 3. These 1D linear chains are interact with adjacent chains through $\mathrm{N}-\mathrm{H}$... Br intermolecular interaction to generate $2 \mathrm{D}$ sheets structure, Figure 3(b), Table 3. Adjacent 2D sheets are further linked to each other to form overall supramolecular structure by cooperation of $\mathrm{C}-\mathrm{H}$.. $\mathrm{Br}$ and $\mathrm{N}-\mathrm{H} . . . \mathrm{Br}$ hydrogen bonds and $\pi \ldots \pi$ interactions, Figure $3(\mathrm{c})$, Table 3.

\section{ACKNOWLEDGMENTS}

We would like to thank the Graduate Study Councils of Islamic Azad University, Omidiyeh Bbranch, for financial support.

\section{REFERENCES}

1. V. T. Yilmaz, S. Caglar, W. T. A. Harrison, Z. Anorg. Allg. Chem., 630, 1126 (2004)

2. J. Halfpenny, R. W. H. Small, Acta Crystallogr., Sect. C: Cryst. Struct. Commun., 53, 438 (1997).

3. A. R. Mahjoub, A. Morsali, R. E.Nejad, Z. Naturforsch., B:Chem. Sci., 59, 1109 (2004). 
4. A. S. Batsanov, C. Bilton, R. M. K. Deng, K. B. Dillon, A. E. Goeta, J. A. K. Howard, H. J. Shephard, S. Simon, I. Tembwe, Inorg. Chim. Acta, 365, 225 (2011).

5. M. Horner, G. M. de Oliveira, J. A. Naue, J. Daniels, J. Beck, J. Organomet. Chem. 691, 1051(2006).

6. G. M. Sheldrick, SADABS, Bruker AXS, Madison, WI, USA, (1998).

7. Bruker SMART and SAINT. Bruker AXS Inc., Madison, WI, USA, (1998).

8. G. M. Sheldrick, Acta Crystallogr, A64, 112 (2008).

9. Mercury 1.4.1, Copyright Cambridge Crystallographic Data Center, 12 Union Road, Cambridge CB2 1EZ, UK, (2001-2005).

10. V. Amani, N. Safari, H. R. Khavasi, Polyhedron, 26, 4257 (2007).
11. V. Amani, N. Safari, H. R. Khavasi, Mirzaei, P. Polyhedron, 26, 4908 (2007).

12. V. Amani, N. Safari, H. R. Khavasi, Akkurt, M. Polyhedron, 28, 3026 (2009).

13. M. Shukla, N. Srivastava, S. Saha, T. R. Rao, S. Sunkari, Polyhedron, 30, 754 (2011).

14. K. Nakamoto, Infrared and Raman Spectra of Inorganic and Coordination Compound Part B: Application in Coordination, Organometallic and Bioinorganic Chemistry; Wiley, New York, (2009).

15. L. Yang, D. R. Powell and R. P. Houser, Dalton Trans., 955 (2007).

16. A. W. Addison, T. N. Rao, J. Reedijk, J. Van Rijn, G. C. Verschoor, J. Chem. Soc., Dalton Trans., 1349 (1984). 